\title{
Permaculture Design: Linking Local Knowledge in Land Use Planning for House Compound
}

\author{
Anizah Mohd Salleh ${ }^{1,}$, Farah Mastura Rosli ${ }^{2}$, Norizan Esa $^{3}$, and Mahamad Hakimi Ibrahim $^{2 *}$ \\ ${ }^{1}$ Faculty of Technical and Vocational, Universiti Pendidikan Sultan Idris, Perak, Malaysia \\ ${ }^{2}$ School of Industrial Technology, Universiti Sains Malaysia, 11800 Pulau Pinang, Malaysia \\ ${ }^{3}$ School of Educational Studies, Universiti Sains Malaysia, 11800 Pulau Pinang, Malaysia
}

\begin{abstract}
Permaculture accounts as among the sustainable practices that incorporates diverse aspects of ecology, landscape, organic farming, forestry, agriculture, architecture, and city planning. However, the increasing loss of local values may indirectly influence the sustainability of the system, since local knowledge is an important source of information that influences permaculture design. This study attempts to understand the knowledge of local people in planning and designing a permaculture system subjected to their livelihood, culture and ecological aspects. In particular, this study identifies land use planning for permaculture zones, and design elements in permaculture zones. The study reviews the planning and design element of permaculture that is significant to understand the ecosystem based design with sustainable practices. The results discussed that local people, regardless of their locations either urban or rural, tend to take into account the natural layout, interior architecture and internal activities in planning and designing the zones for their house compound. The zoning is not only beneficial for efficient energy use, but also sustainable both in environmental, social and economic aspects appropriate to the livelihood and culture of local people. Therefore, local knowledge should be considered when designing a permaculture system, as it is likely to design with nature rather than design against nature.
\end{abstract}

\section{Introduction}

Permaculture has been recognized as a new ecological paradigm of sustainable practices, together with sustainable development in diverse aspects of ecology, landscape, organic farming, forestry, agriculture, architecture, and city planning [1]. These sustainable practices were adopted both in urban and rural areas as a contribution to environmental protection and acknowledged as ecological design for human settlements. To ecologically design, preserve and maintain natural systems, 12 permaculture design principles considering natural patterns need to be followed $[1,2]$. Those are creative usage and response to change; observe and interact; catch and store energy; obtain a yield; self-

regulate and accept feedback; renewable use and value; produce no waste; design from pattern to detail; integrate; use small and slow solutions; use and value diversity; and use edges and value the marginal. These 12 design principles can be regarded as a guideline for ecosystem based design, which indicate the ecological processes of planning and designing.

Despite all its merits, conventional sustainable practices adoption with respect to local knowledge is rarely considered in planning and designing processes. The situation has contributed to the failure of sustainable practices that caused by ignorance of nature's pattern [3]. It has led to several disadvantages towards preserving the values of natural systems in sustainable practices, for example, the loss of natural topography beneficial for climatic protection and abundance of plant species rarely consumed by the local people. Other than that, it would be difficult to protect local ecosystem with respect to their local knowledge, and these causes the decreasing of appreciation of local culture among local people. Therefore, the aim of this study is to understand the knowledge of local people in planning and designing a permaculture system subjected to their livelihood, culture and ecological aspects. Two objectives are embedded in this study that is to identify i) land use planning for permaculture zones, and ii) design elements in permaculture zones. These aim and objectives are studied with respect to one of the permaculture design principles 
which is design from pattern to detail, interestingly focusing on the influence of local knowledge in planning and designing for house compound.

\section{Literature review}

\subsection{The novelty of permanent agriculture concept}

The ideas of permaculture, derived from permanent agriculture developed by Bill Mollison and assisted by David Holmgren in 1978, are generating an increasing interest as an approach to natural resources management. This system focused on the ecosystem based design, concerning fundamental factors in ecosystem services of supporting, provisioning, regulating, and cultural $[4,5]$. This kind of approach is beneficial to life in all its forms by designing sustainable human settlement as well as preserving and maintaining natural system. In many contexts, permaculture is considered as a holistic approach, especially when it involved permaculture ethics and design principles in planning and designing the permaculture sites as it deals with ecosystem in order to obtain sustainability [3, 6]. Encouraging more environmentally development of ecosystem based design with concern of natural cycle, multi-product, and setting limit for population and consumption, is therefore defined the novelty of permanent agriculture concept.

\subsection{Pattern for land use planning and designing}

The recurring question of planning and designing permaculture sites is whether and to what extent patterns of land use planning has affected the natural system of permaculture. Natural system clearly involved the ecological processes of human, plants, animal, nutrient cycle, climatic cycle, and weather cycle that harmoniously integrated and complement each other [3]. In line with this, theoretically, planning involves a hands-on or on-site process, while designing is a kind of environmental analysis in which patterns are developed based on the existing situations or structures [1]. Empirically, pattern, in this context refers to the natural features of permaculture sites include topography, soils, hydrography, climatic factor and orientation, vegetation, and wildlife. Therefore, the process of planning and designing a permaculture sites through hands-on or on-site process which consider natural patterns are seen as viable art, science and design development. It is subjected to its advantages in providing greatest impacts and values for the surrounding ecosystem since the planning and designing processes follows the design principles of ecosystem based design. The rationale for patterns in planning and designing permaculture sites is explained through the involvement of landscape by dividing the pattern into zones. Basically, zone planning is a system where elements are designed to be located in certain zoning areas and depends on the regularity of the elements to be used and maintained. For example, herbs to be used in the household kitchen are located in one zone. Another zone may contain the chicken coop, a pond, shrubs and short trees that provide food for the household forming a food forest. Larger and taller fruit trees is located in a third zone further away from the main house while the last zone that may be the furthest away is usually the natural forested area that serves as a supply of firewood and for foraging. Thus different zones require different energy efficiency. In this manner, zones are important for efficient energy planning. Such importance includes designing elements such as trees and plants, animals, and structure and building to be integrated in the zones.

\subsection{Approaching permaculture adoption towards local knowledge}

Permaculture is an extremely complex system with ecosystem based design for land use and lifestyle. The most obvious relation of permaculture to local ecosystem and knowledge is based on man and nature relationship [7]. Such relationship can be seen through human livelihood interdependence on health and productivity of ecosystem. Natural system may be used positively or negatively depends on how the local knowledge are being used in planning and designing an ecosystem, but human stewardship surprisingly play a vital role in shaping the environment as human is an integral part of nature [8]. In other cases, zones of permaculture should be designed based on natural pattern and necessity of elements step by step through observation, visioning, planning, development, and implementation to avoid harmfulness both to human and environment [6]. 


\section{Methodology}

This study is based on the qualitative research methodology by adopting document analysis to identify the influence of local knowledge in planning and designing permaculture system. In details, it is to study how local ecosystem and knowledge could positively contribute to the sustainability of permaculture zones with respect to the livelihood, culture and ecological aspect. The document analysis involves particular review on the current permaculture issues with respect to the local needs, lifestyles, culture, and ecosystem. Importantly, the selection of document analysis is based on the permaculture practices in tropical countries.

\section{Results}

A total of five (5) zones for land use planning were identified and three (3) design elements were considered in this study. Normally, the permaculture zones are involving zone 1, 2, 3, 4, and 5. The functionality of these zones is subject to the 3 design elements of trees and plants, animals, and structure and buildings. The characteristic of zones and its relationship with design elements is shown in Table 1 . The overall land use planning and design elements indicate that the suitability and accuracy of permaculture zones are influenced by the natural pattern of the surrounding. Those are topography, soils, hydrography, climatic factor and orientation, vegetation, and wildlife.

Table 1. Character of permaculture zones and its relationship with design elements.

\begin{tabular}{|c|c|c|c|c|c|}
\hline & Zone 1 & Zone 2 & Zone 3 & Zone 4 & Zone 5 \\
\hline $\begin{array}{l}\text { Location / } \\
\text { Size }\end{array}$ & $\begin{array}{l}\text { Near to the } \\
\text { building or } 1 / 4 \\
\text { acre }\end{array}$ & 1 acre & 4 to 20 acre & Any size & Any size \\
\hline $\begin{array}{l}\text { Land use } \\
\text { intensity }\end{array}$ & $\begin{array}{c}\text { High } \\
\text { intensity: } \\
\text { frequently } \\
\text { visited }\end{array}$ & $\begin{array}{c}\text { Semi- } \\
\text { intensely } \\
\text { cultivated }\end{array}$ & $\begin{array}{l}\text { Occasionally } \\
\text { visited }\end{array}$ & Minimal care & Unmanaged \\
\hline Accessibility & Very good & Good & Good & Poor & Very poor \\
\hline $\begin{array}{l}\text { Design } \\
\text { element }\end{array}$ & $\begin{array}{c}\text { Kitchen } \\
\text { garden: small } \\
\text { trees, } \\
\text { rainwater } \\
\text { tank } \\
\end{array}$ & $\begin{array}{c}\text { Food } \\
\text { production }\end{array}$ & $\begin{array}{c}\text { Large fruit } \\
\text { trees } \\
\text { Livestock: } \\
\text { forage system }\end{array}$ & $\begin{array}{l}\text { Food forest } \\
\text { Livestock: } \\
\text { self forage } \\
\text { system }\end{array}$ & $\begin{array}{c}\text { Timber } \\
\text { trees } \\
\text { Inspiration } \\
\text { Meditation }\end{array}$ \\
\hline $\begin{array}{l}\text { Energy } \\
\text { efficiency }\end{array}$ & $\begin{array}{c}\text { Low energy } \\
\text { usage }\end{array}$ & $\begin{array}{c}\text { Low energy } \\
\text { usage }\end{array}$ & $\begin{array}{l}\text { Intermediate } \\
\text { energy usage }\end{array}$ & $\begin{array}{c}\text { High energy } \\
\text { usage }\end{array}$ & $\begin{array}{c}\text { High energy } \\
\text { usage }\end{array}$ \\
\hline
\end{tabular}

Based on Table 1, the overall operation of permaculture design will influence the energy efficiency of the system. However, the accessibility of the zones will be determined by the land use intensity which symbolized the regularity of the elements usage and maintenance, not the standard immensity of each zone. Due to human intervention such as interior architecture and internal activities of existing building, zone 1 always requires high attention of human activities in order to maintain the functionality of the zone. In contrast, this zone only involves low energy usage as the distance is near to the building, and thus it has very good accessibility as the area is frequently visited subjected to the existence of intensively used as design elements. Therefore, the nearer the zone of the existing building, the highest land use intensity and accessibility, but involved the lowest energy usage. In particular, the most necessary design elements are placed closest to the existing building, which can be easily maintained and accessed by human.

\section{Discussion}

\subsection{Motivation for permaculture}

House compound can be seen to satisfy and serve many functions in fulfilling the basic need of human life. The function is reflected by the interior architecture and internal activities of the house, including the natural layout of house compound. The control over house compound was planned by zones and designed by elements through ecosystem based design approach. It is worth noting that efficient energy use can be endorsed to achieve balance and harmony design in response to natural pattern of house compound. In this way, people can save their energy subjected 
to the high intensity use of the zones and elements. In relating permaculture zones with local knowledge, it is concerning the usefulness of house compound for each zone, for example an area to reflect joyful and aesthetic, route to connect different zones, and space for kitchen activities. Demonstrating efficient energy use was highly important in this study, but meeting the suitability of the space with the right activities and harmony patterns would increased the values of the permaculture design with respect to local knowledge. This may reflect the fact that ecosystem based design has already following the novelty of permaculture in which to design sustainable human settlement and preserve as well as maintain the natural system. In many cases of landscape design, local ecosystem and knowledge do play its role in planning and designing of house compound by adopting man and nature relationship.

\subsection{Implications for linking local knowledge in permaculture}

Although sustainable practices were important, planning and designing with nature through ecosystem based design with respect to local knowledge did not seem vital for the local culture. Local knowledge was not clearly seen as part of the influential factor in planning and designing for ecological processes. Notably, from this study, there was significant correlation between permaculture design and local values. There is an opportunity to enhance the permaculture values through natural pattern and layout of house compound and change the perception of ecosystem based design is only beneficial for natural system. With the ethical values and design principle of permaculture, the ecosystem based design will have to consider the local knowledge in order to create permaculture system that can be adopted for both urban and rural areas. This is subjected to the fact that permaculture design need to reflect on the livelihood and culture of urban and rural communities rather than only focusing on the ecological or natural layout of house compound as shown in

Figure 1.

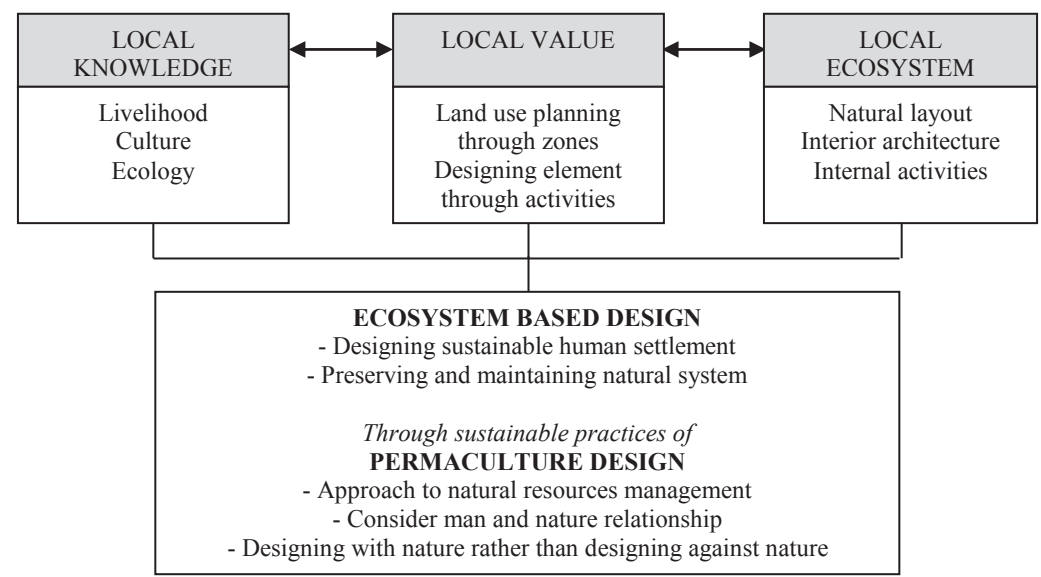

Fig. 1. Relationship between permaculture design and local knowledge, value and ecosystem in planning and designing house compound for ecosystem-based design project.

\section{Conclusion}

Designing with nature rather than designing against nature represents an ecosystem-based design that illustrates sustainable practices in diverse aspects. This permaculture system is immersed with planning and designing by following the natural patterns of permaculture sites. As such, permaculturist must understand the elements of permaculture in detailed as well as able to find the appropriate pattern of permaculture design. Like other sustainable practices, permaculture is established with regards to the local ecosystem and perhaps it is even more local knowledge scrutiny especially in land use planning and designing. In response, the understanding on how permaculture operates is related to the ethic and principles of permaculture. It is driven from pattern analysis, which constitute visual 
embodiment of nature's knowledge through observation of our sense and practical knowledge through the pattern as representation of human activity.

\section{Acknowledgement}

The authors express their gratitude to the Malaysian Ministry of Higher Education for awarding the Long-Term Research Grant (LRGS, 203/PTS/6727002) and the Knowledge Transfer Programme (KTP, 203/PGURU/6750077) and Universiti Sains Malaysia as well as all involved in this study.

\section{References}

1. K. Rothe, Communication +1 (2014)

2. T. Raberg, The Swedish University of Agricultural Science (2007)

3. A. Faiza, A. L. Suleman, S. K. Safdar, S. Farhana, Journal of Environmental Management, 179, 31-37 (2016)

4. W. V. Reid, H. A. Mooney, A. Cropper, D. Capistrano, S. R. Carpenter, K. Chopra, P. Dasgupta, T. Dietz, A. K. Duraiappah, R. Hassan, R. Kasperson, R. Leemans, R. M. May, T. A. J. McMichael, P. Pingali, C. Samper, R. Scholes, R. T. Watson, A. H. Zakri, Z. Shidong, N. J. Ash, E. Bennett, P. Kumar, M. J. Lee, C. Raudsepp-Hearne, H. Simons, J. Thonell, M. B. Zurek, Millennium Ecosystem Assessment (2005)

5. L. Calvet-Mir, E. Gomez-Baggethun, V. Reyes-Garcia, Ecological Economics, 74, 153-160 (2012)

6. T. Hemenway, A Guide to Home-Scale Permaculture, (2001)

7. M. H. Nur Huzeima, A. Suriati, Procedia - Social and Behavioral Sciences, 42, 182-189 (2012)

8. P. Bourdeau, Journal of Environmental Radioactivity, 72, 9-15 (2004) 